\title{
Helicobacter pylori: a poor man's gut pathogen?
}

\author{
Mohammed Mahdy Khalifa', Radwa Raed Sharaf², Ramy Karam Aziz ${ }^{1 *}$
}

\begin{abstract}
Helicobacter pylori is one of the human pathogens with highest prevalence around the world; yet, its principal mode of transmission remains largely unknown. The role of $H$. pylori in gastric disease and cancer has not been established until the end of the $20^{\text {th }}$ century. Since then, its epidemiology has been extensively studied, and an accruing body of literature suggests that not all humans are equally at risk of infection by this gut pathogen. Here, we briefly review the different epidemiological aspects of $H$. pylori infection with emphasis on those factors related to human poverty. The epidemiology of $\mathrm{H}$. pylori infection is characterized by marked differences between developing and developed countries, notably among children. In addition, congruent lines of evidence point out to socioeconomic factors and living standards as main determinants of the age-dependent acquisition rate of H. pylori, and consequently its prevalence. These data are alarming in the light of the changing global climate and birth rate, which are expected to change the demography of our planet, putting more children at risk of H. pylori and its complications for years to come.
\end{abstract}

\section{Introduction}

Helicobacter pylori, formerly known as Campylobacter pyloridis then Campylobacter pylori, is one of the human pathogens with highest prevalence around the world; yet, its exact mode of transmission is still uncertain. This organism was isolated from the human stomach but has not been consistently isolated from any other niche, and thus the mechanism by which it colonizes the human stomach remains largely unknown.

H. pylori is a spiral, gram-negative, microaerophilic bacterium, which was established in 1982 by Robin Warren and Barry Marshall as the causative agent of gastritis and peptic ulcer [1,2], a discovery that revolutionized gastroenterology. Before Warren and Marshall, the human stomach was believed to be a sterile area. Today, $H$. pylori is recognized as the most common cause of gastritis, which in turn leads to the development of more gastrointestinal complications such as peptic and duodenal ulcers. Additionally, the organism is classified as a class 1 carcinogen because of its causal relationship to gastric adenocarcinoma, one of the world's deadliest cancers $[3,4]$.

The previously underestimated clinical relevance of this rediscovered spiral bacterium quickly enticed microbiologists, epidemiologists, infectious disease specialists,

\footnotetext{
* Correspondence: ramy.aziz@salmonella.org
'Department of Microbiology and Immunology, Faculty of Pharmacy, Cairo

* Correspondence: ramy.aziz@salmonella.org
'Department of Microbiology and Immunology, Faculty of Pharmacy, Cairo University, 11562 Cairo, Egypt
}

C 2010 Khalifa et al; licensee BioMed Central Ltd. This is an Open Access article distributed under the terms of the Creative Commons Attribution License (http://creativecommons.org/licenses/by/2.0), which permits unrestricted use, distribution, and reproduction in any medium, provided the original work is properly cited.

and veterinarians to explore its physiology, genetics, epidemiology, and transmission. Such scientific activity was translated into more than 40,000 scientific articles about H. pylori in the past 20 years (Fig. 1A). During these 20 years, the number of $H$. pylori-related articles in PubMed http://www.ncbi.nlm.nih.gov/pubmed became comparable to the number of articles about well-established pathogens such as Staphylococcus aureus and Mycobacterium tuberculosis (Fig. 1B).

The growing attention given to $H$. pylori by academics and clinicians is not surprising since this pathogen colonizes more than half of the world's inhabitants [5], with an evident geographic variation in its epidemiology. This geographic variation is believed to be largely socioeconomically driven on both global and local scales. Other factors have also been reported to influence the incidence and prevalence of $H$. pylori, such as age, gender, genetic predisposition, ethnicity, educational level, and sanitation. Yet, the remarkably unequal burden of $H$. pylori-associated diseases on poorer communities and countries is the focus of this review article.

\section{Epidemiology of $\boldsymbol{H}$. pylori Infection Prevalence of $H$. pylori infection}

$H$. pylori is one of the most common bacterial infectious agents; it inhabits the stomachs of more than half of the world's population [5]. The prevalence of infection seems to mostly depend on the rate of acquisition (see 
A.

\section{H. pylori Literature}

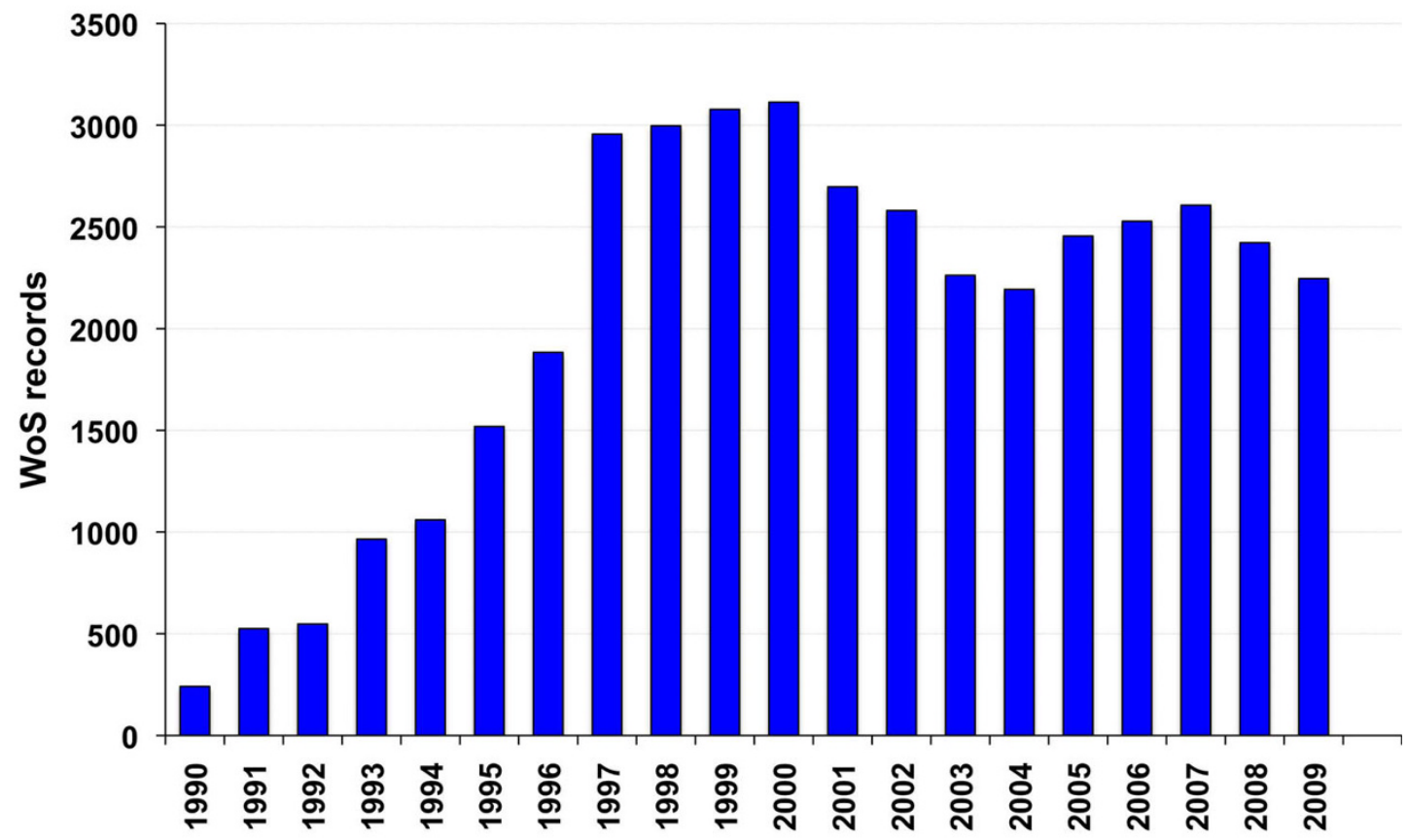

B.

\section{PubMed Records}

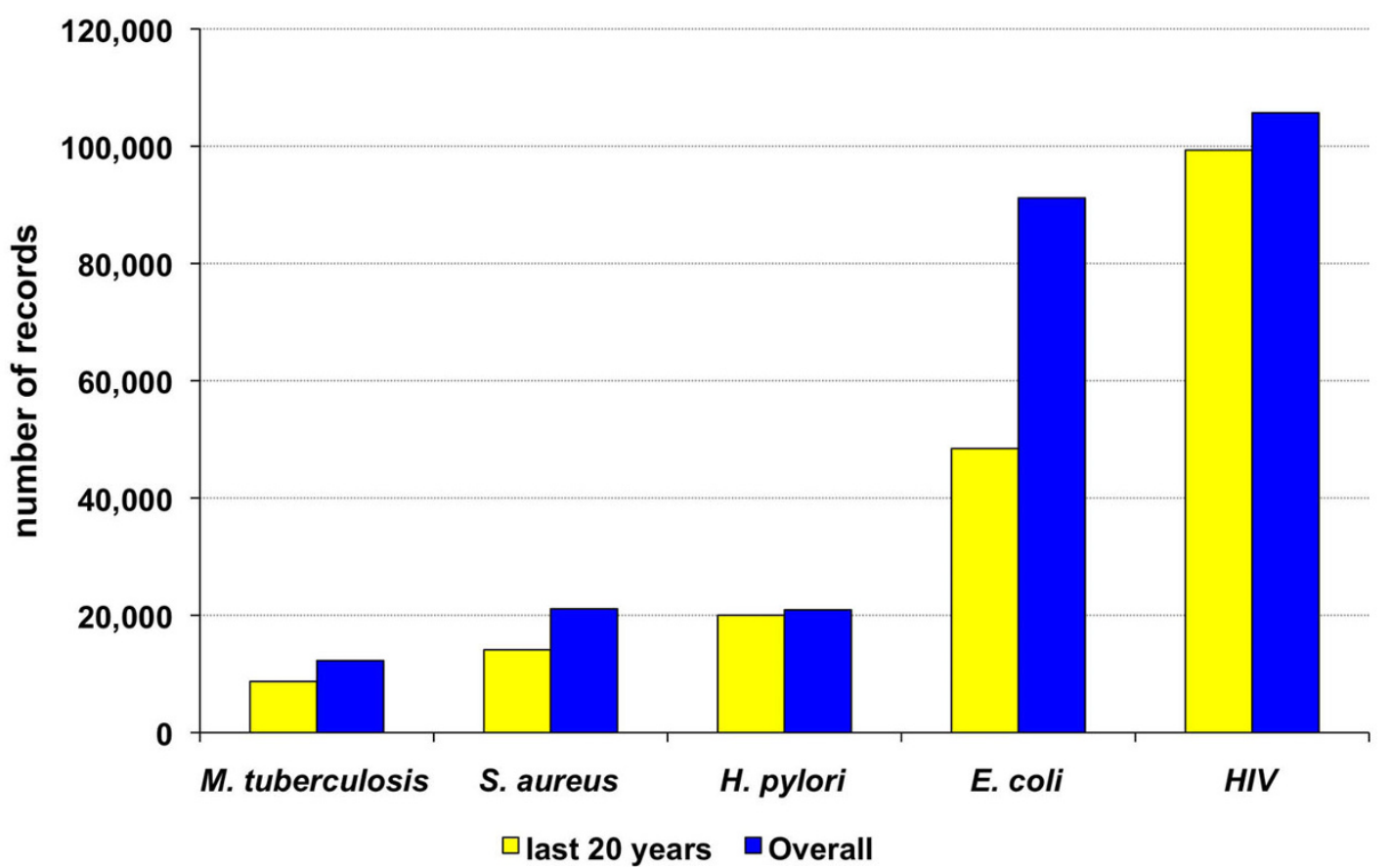

Figure 1 A. H. pylori-related articles published between 1989 and 2009. Data are collected from search results on ISI Web of Science (WoS, URL: http://www.isiwebofknowledge.com) with "Helicobacter pylori OR H. pylori" as search string. B. Example infectious agents in literature The PubMed literature database (URL: http://www.ncbi.nlm.nih.gov/pubmed) was searched for articles whose titles include the words: Mycobacterium tuberculosis (M. tuberculosis), Staphylococcus aureus (S. aureus), Helicobacter pylori (H. pylori), Escherichia coli (E. coli), and the human immunodeficiency virus (HIV). Although H. pylori is a recently discovered pathogen, it has more records in literature than well-established pathogens such as S. aureus and M. tuberculosis but is exceeded by HIV and E. coli, the latter being possibly the most cited bacterium and the most commonly used organism in the laboratory. 
below), but also on the rate of loss of infection [6] and the length of the persistence period between acquisition and loss [7]. Based on these factors, H. pylori prevalence differs from one country to another and may differ between different ethnic, social, or age groups within the same country [6,8-11].

Globally, the prevalence of $H$. pylori infection in developing countries is markedly higher than that in developed countries [12-16]. Moreover, the acquisition of H. pylori seems to occur at higher rates in developing countries $[7,9]$. A plethora of studies reported and emphasized these differences within and between countries (Table 1).

\section{Incidence of $H$. pylori infection}

The geographic differences in $H$. pylori prevalence have been attributed to the differential rate of acquisition of the bacterium during the first years of life $[5,6,9,17,18]$. In southern China, for example, the prevalence of $H$. pylori infection was shown to be significantly higher among Chinese subjects than that among Australians, a difference that was associated with the rate of acquisition of $H$. pylori under the age of ten years $[9,11]$.

Acquisition of $H$. pylori is decreasing in developed countries at a faster rate than in developing countries, likely because of the faster improvement in hygiene practices in the developed world [5,19]. Moreover, infection during childhood in developed countries is not frequent [20-23]. In the United States, for example, the incidence of infection among children younger than five years is less than $5 \%$, and only about $10 \%$ of the population is infected by adolescence [20,21]. By contrast, the incidence of $H$. pylori infection in the developing world is higher and occurs at younger age $[22,24]$. By five years of age, about $50 \%$ of children in developing countries are already infected $[12,24]$, and the infection rates in adults can reach $90 \%$ or higher (Table 1).

Pounder and Ng classified the world into two groups according to the incidence of $H$. pylori infection [7]. Group One consisted of countries where the majority of children become infected with $H$. pylori during childhood, while chronic infection continues during adult life. These are mostly developing countries, e.g., Algeria, Nepal, South Africa, Saudi Arabia, Thailand, and Vietnam. In Group Two, mostly comprising developed countries, only a minority of children becomes infected during childhood, but the prevalence of infection rises with age during adulthood. Examples of Group Two countries are England, Finland, France, Japan, and the United States of America [7]. However, Pounder and $\mathrm{Ng}$ concluded their synthesis with an
Table 1 Prevalence of $H$. pylori infection in different populations of the world.

\begin{tabular}{|c|c|c|c|c|}
\hline Country & $\begin{array}{l}\mathrm{N} \text { studied } \\
\text { cases }\end{array}$ & $\begin{array}{l}\text { Age range } \\
\text { (years) }\end{array}$ & $\begin{array}{l}\text { Pre- } \\
\text { valence }\end{array}$ & Ref. \\
\hline \multicolumn{5}{|c|}{ Developing Countries ${ }^{1}$ : } \\
\hline Bangladesh & 181 & $20-44$ & $92 \%$ & {$[95]$} \\
\hline \multicolumn{5}{|l|}{ Brazil } \\
\hline \multirow[t]{2}{*}{ - rural } & 40 (children) & $<20$ & $77.5 \%$ & \\
\hline & 164 (adults) & $20-90$ & $84.7 \%$ & {$[96]$} \\
\hline - urban & 363 & $>20$ & $63.4 \%$ & {$[97]$} \\
\hline $\begin{array}{l}\text { - poor urban } \\
\text { community }\end{array}$ & 204 & $18-80$ & $80 \%$ & {$[98]$} \\
\hline Colombia (rural) & 684 & $2-9$ & $69 \%$ & [99] \\
\hline \multicolumn{5}{|l|}{ China } \\
\hline - Southern China & 1727 & N/A & $44.2 \%$ & {$[9]$} \\
\hline - Hong Kong & 397 & $36-65$ & $58.6 \%$ & [100] \\
\hline - Changle of Fujan & 1456 & & $80.4 \%$ & [100] \\
\hline
\end{tabular}

Egypt

- Alexandria $\quad 169$ mothers N/A $88 \%$

(northern)

\begin{tabular}{lllll} 
& 169 children & $<1$ & $13 \%$ & \\
& & 1.5 & $25 \%$ & {$[101]$} \\
- Cairo (central) & 52 & $<6$ & $33 \%$ & \\
& 56 & $>6$ & $60 \%$ & {$[102]$} \\
- Assiut (southern) & urban & $\mathrm{N} / \mathrm{A}$ & $87 \%$ & \\
& rural & $\mathrm{N} / \mathrm{A}$ & $40 \%$ & {$[103]$} \\
- poor urban area & schoolchildren & $\mathrm{N} / \mathrm{A}$ & $72.4 \%$ & {$[104]$} \\
\hline India & 238 & $3-70$ & $79 \%$ & {$[13]$} \\
\hline Mexico & 11605 & $20-90$ & $66 \%$ & {$[61]$} \\
\hline Nepal (rural) & 1142 & $4-93$ & $56.8 \%$ & {$[69]$} \\
\hline Peru & 407 & 2 mo-12 yr & $48 \%$ & {$[105]$} \\
& 104 & $0-17$ & $50 \%$ & {$[70]$} \\
\hline Russia & 213 & $20-75$ & $88 \%$ & {$[106]$} \\
- St. Petersburg 1995 & 307 & $2-19$ & $44 \%$ & {$[18,106]$} \\
- St. Petersburg 2005 & 370 & $2-19$ & $13 \%$ & {$[18]$} \\
\hline Saudi Arabia & 557 & $5-10$ & $40 \%$ & {$[107]$} \\
& & $>20$ & $70 \%$ & \\
\hline Taiwan & 823 & $1-40+$ & $54 \%$ & {$[78]$} \\
\hline Developed Countries ${ }^{1}:$ & & & \\
Australia (urban & 273 & $19-47$ & $23 \%$ & {$[32]$} \\
Melbourne) & & & & \\
\hline Denmark & 3589 & $30-60$ & $25.9 \%$ & {$[108]$} \\
\hline Germany (western) & 260 & $18-61$ & $39.2 \%$ & {$[60]$} \\
\hline Israel (rural) & 377 & $30-90$ & $72 \%$ & {$[109]$} \\
\hline Japan & 4361 & $19-69$ & $30 \%$ & {$[110]$} \\
\hline Netherlands & 254 & $11-89$ & $27.2 \%$ & {$[111]$} \\
\hline New Zealand & 579 workers: & $40-64$ & $56 \%$ & \\
- Europeans & 190 & & $35.8 \%$ & \\
- Maori & 195 & & $57.4 \%$ & \\
- Pacific Islanders & 194 & & $73.2 \%$ & {$[64]$} \\
\hline & & & \\
\hline
\end{tabular}


Table 1: Prevalence of $\boldsymbol{H}$. pylori infection in different populations of the world. (Continued)

\begin{tabular}{lllll}
\hline Spain & 332 & $>18$ & $43 \%$ & {$[112]$} \\
- mountain & $178^{2}$ & & $54 \%$ & \\
- coastal & 154 & & $30 \%$ & \\
\hline South Korea & 161 & $20-75$ & $75 \%$ & {$[113]$} \\
\hline Switzerland & 176 natives & $10-20$ & $7.3 \%$ & {$[81]$} \\
& 20 immigrants & & $30 \%$ & \\
\hline United Kingdom & & & & \\
- England & 267 (healthy) & $>18$ & $41 \%$ & {$[114]$} \\
& 467 (all males) & $18-65$ & $37.5 \%$ & {$[115]$} \\
- Northern Ireland & 4742 & $12-64$ & $50.5 \%$ & {$[116]$} \\
- South Wales & 1796 & $45-59$ & $70 \%$ & {$[117]$} \\
\hline United States & \multicolumn{3}{l}{} & \\
- South Carolina & 938 army & $17-26$ & $26 \%$ & \\
& recruits & & & \\
& 324 blacks & & $44 \%$ & \\
& 47 Hispanics & & $38 \%$ & \\
& 536 whites & & $14 \%$ & {$[66]$} \\
- California & 556 & $20-39$ & $27 \%$ & {$[67]$} \\
- Texas & 246 blacks & $15-80$ & $70 \%$ & \\
& 239 whites & & $34 \%$ & {$[59]$} \\
\hline
\end{tabular}

Examples of differences in $\mathrm{H}$. pylori prevalence within and between countries, representing the developing and developed world.

1. The classification into developing or developed countries was retrieved from the United Nation Development Programme's Human Development Reports (URL: http://hdr.undp.org/en)

2. The number reported in the article was 179 , which is likely a typographical error.

N/A: Data not available or not applicable

interesting question. Do the age-dependent prevalence data reflect that people in Group Two have more incidence of infection at older ages, or do the data rather reflect that the incidence of infection is declining in newer generations, which implies that the infected adults had been actually infected in their childhood [7]? This question was effectively answered later on, as longitudinal studies confirmed the birth cohort effect in the United States [6] and Russia [18], for example.

\section{Transmission of $\boldsymbol{H}$. pylori infection}

I. Direct transmission [For a detailed review, see Ref. [11]] The mode of transmission of $H$. pylori is one of the most controversial areas in the study of this pathogen. Ingestion of the bacteria, which is the most likely portal of entry, may occur by one or a combination of three means: oral-oral, gastro-oral, or fecal-oral, but determining a dominant route is not an easy task. While culturing $H$. pylori from the gastric secretion is possible, its isolation from stool or the oral cavity is difficult because either location is known for its diverse, abundant resident microbiota. Many members of this microbiota outgrow H. pylori, masking its colo- nies if present, unless a discriminating selective culture medium is used [11].

\section{1) Oral-oral transmission}

Although $H$. pylori was suggested as a member of the oral microbiota, independent from the stomach's infection status [25], and although the prevalence of $H$. pylori infection among dentists or dental workers is not higher than in others [26,27], the mouth is still being considered as a candidate reservoir for $H$. pylori, and oral-oral transmission is regarded as a plausible route of $H$. pylori transmission. Recent studies reported that exposure to persons with $H$. pylori-induced gastroenteritis is a risk factor for new infection [28], while experiments with rhesus macaques supported the hypothesis that oral-oral transmission is the most likely route of transmission [29]. This mode of transmission can be potentiated by specific eating habits, such as the premastication of food by mothers before feeding children in some African countries [30], and the use of chopsticks and communal eating in some immigrant Chinese communities [31,32], although the chopstick hypothesis has been challenged [33].

Detection of $H$. pylori-specific DNA from the oral cavity was reported [e.g., [34-36]], and even though isolating these bacteria from the oral cavity is difficult because of the presence of fast-growing microbiota, strains, identical to those isolated from the stomachs of the same patients, were successfully cultured [37-39]. On the other hand, several other studies failed to detect $H$. pylori-specific DNA from the oral cavities of H. pylori-positive patients [e.g., [40,41]].

\section{2) Gastro-oral transmission}

Since the human stomach is the primary niche of H. pylori, it is reasonable to suggest a direct gastro-oral route of transmission mediated by refluxed gastric juice $[11,42]$. This hypothesis is supported by several studies in which $H$. pylori was detected in the gastric juice $[33,43-46]$ as well as the vomitus of infected subjects, and even from the air sampled during the vomiting process [47]. Additionally, a high rate of active $H$. pylori infection was detected by the ${ }^{13} \mathrm{C}$ urea breath test in siblings of $H$. pylori-infected vomiting children [42].

The gastro-oral hypothesis also explains earlier reports of epidemic gastritis in subjects undergoing repeated gastric secretory studies $[48,49]$, as well as observations of higher prevalence of $H$. pylori in gastroenterologists performing endoscopy [26].

\section{3) Fecal-oral transmission}

H. pylori is sensitive to the bile's bactericidal effect, so theoretically, and under normal conditions, passage of 
viable $H$. pylori through the intestine and its detection in stool are unlikely $[11,50]$; yet, some studies suggest that passage of viable $H$. pylori through the intestine could be verified [e.g., [51]]. While $H$. pylori-specific DNA was successfully detected in the fecal samples from as few as $10 \%$ to as many as $90 \%$ of subjects with known $H$. pylori infection [52-55], detection of $H$. pylori-specific DNA is obviously not a sufficient evidence for bacterial viability [11].

After several attempts for culturing $H$. pylori from fecal samples failed, viable bacteria were successfully isolated from one adult and 23 children in Gambia [56], and 12 adults in the United Kingdom [57]. Nevertheless, attempts to reproduce these results using similar techniques failed, which led to the suggestion that the malnourishment of Gambian children and their short fecal transit time are the reasons behind the exceptional isolation of $H$. pylori from fecal samples [58]. In support of the latter hypothesis, Parsonnet and colleagues showed that inducing diarrhea with a cathartic made culturing H. pylori from stool samples possible, also suggesting that gastrointestinal tract illnesses might increase H. pylori transmissibility [47].

\section{Indirect transmission}

Environmental or animal reservoirs were investigated as sources of $H$. pylori infection. Food, animals, and water sources have been suggested as reservoirs outside the human gastrointestinal tract, and $H$. pylori or its DNA was detected in each of these sources (Table 2). However, there is no definitive evidence that they are natural or primary vehicles of transmission.

\section{Genetic and Environmental Determinants of H. pylori Epidemiology \\ Age}

The effect of age on the prevalence of $H$. pylori is one of the best-documented and least disputed aspects of $H$. pylori epidemiology. A positive correlation between age and prevalence has been reported in both developed and developing countries [for example, [8,59-61]]. Consistently, the prevalence of infection was found to be higher in adults than that in children, and this pattern has been interpreted to partly reflect a birth cohort phenomenon caused by a higher incidence in the past due to poor living conditions and sanitation $[18,35,62,63]$.

A comprehensive longitudinal study undertaken by Fujisawa et al. evaluated changes in the seroepidemiological pattern of $H$. pylori in a group of Japanese people over a 20-year period [63]. Sera were collected from 1015 subjects, and the overall prevalence of $H$. pylorispecific antibodies was $72.7 \%$ in $1974,54.6 \%$ in 1984 , and $39.3 \%$ in 1994 . The prevalence of $H$. pylori was found to be positively correlated with age, suggesting that there was a clear cohort-shift in the seroepidemiological pattern of $H$. pylori during the 20 years studied [63].

\section{Ethnic and genetic predisposition}

Marked differences in $H$. pylori seroprevalence have been observed and reported among various ethnic and racial groups $[10,14,64]$. For example, in Malaysia, the increased risk of $H$. pylori infection in Chinese and Indians was suggested as an inherent ethnic genetic predisposition [10]. In New Zealand, ethnicity was suggested as a risk factor among different groups in the populations. $H$. pylori infection was most prevalent in Pacific Islanders, intermediate in Maori, and least prevalent in Europeans. Even after the adjustment of confounding factors, such as age and socioeconomic status, ethnicity remained a significant covariate [64].

By contrast, in a study conducted in USA, the prevalence of $H$. pylori infection was almost identical between Hispanic and African Americans, but significantly higher than that among Caucasians. However, ethnicity was ruled out as a major factor and the observed variance was attributed to socioeconomic conditions [8]. Finally, a study of monozygotic and dizygotic twins suggested also that genetic factors might have some influence on the incidence of $H$. pylori infection [65].

\section{Gender}

An excess of $H$. pylori prevalence in one gender versus the other has been reported [66-68]; for instance, Woodward and colleagues observed a higher prevalence of $H$. pylori in men than in women [68]. Others found no gender-related difference in the prevalence of H. pylori infection $[10,64,69,70]$. A more recent, more comprehensive meta-analysis of large, population-based studies concluded a male predominance of $H$. pylorirelated diseases in adults but not in children [71].

\section{Interfamilial relations}

Many studies reported an influence of interfamilial relation on the spreading of $H$. pylori infection and highlighted adult-child transmission [72-74]. Konno and coworkers suggested mother-to-child transmission as the single most probable cause of the interfamilial spreading of $H$. pylori infection after a five-year followup study. Among 44 children enrolled in that study, five children acquired $H$. pylori infection, and their bacterial isolates exhibited DNA fingerprinting patterns identical to those of their mothers [74]. Family size has also been shown to positively affect $H$. pylori infection incidence; 
Table 2 H. pylori reservoirs.

\begin{tabular}{|c|c|c|}
\hline Hypothesis & Evidence/Example studies & Ref. \\
\hline \multicolumn{3}{|l|}{ Food } \\
\hline $\begin{array}{l}\text { - Contaminated food prepared under unhygienic } \\
\text { conditions is a probable mechanism for } \\
\text { transmission. }\end{array}$ & $\begin{array}{l}\text { A positive correlation was reported between prevalence of infection and } \\
\text { consumption of food from street vendors in Peru. }\end{array}$ & {$[70]$} \\
\hline $\begin{array}{l}\text { - The daily amount of raw vegetables is a risk } \\
\text { factor, which possibly implies a role for water too. }\end{array}$ & $\begin{array}{l}\text { In the Colombian Andes, frequent consumption of raw vegetables was } \\
\text { associated with likelihood of infection. }\end{array}$ & [99] \\
\hline $\begin{array}{l}\text { - Sheep and cow milk can be vehicles for } \\
\text { transmission. }\end{array}$ & See below (under Animals) & {$[118,119]$} \\
\hline \multicolumn{3}{|l|}{ Animals } \\
\hline - Several animal species were suggested as & H. pylori was isolated from: & \\
\hline \multirow[t]{6}{*}{ H. pylori reservoirs. } & - pigtailed monkeys & [120] \\
\hline & - rhesus monkeys & {$[121]$} \\
\hline & - cats & [122] \\
\hline & - sheep & [123] \\
\hline & - cockroaches & {$[124]$} \\
\hline & - houseflies (but the housefly hypothesis was challenged) & {$[125,126]$} \\
\hline \multirow[t]{3}{*}{$\begin{array}{l}\text { - Working with animals may increase risk, and } \\
\text { animal-to-human transmission is possible. }\end{array}$} & $\begin{array}{l}\text { H. pylori was suggested as zoonotic, occupational infection to meat and } \\
\text { abattoir workers. }\end{array}$ & {$[127,128]$} \\
\hline & $\begin{array}{l}\text { In Colombian Andes, children who had contact with sheep had higher } \\
\text { prevalence odds. }\end{array}$ & [99] \\
\hline & $\begin{array}{l}\text { Dore et al. stated that animals, especially sheep and dogs, could transmit } \\
\text { H. pylori to humans (shepherds) in Sardinia. }\end{array}$ & [129] \\
\hline - H. pylori can be recovered from animal products. & H. pylori was recovered from sheep and cow milk. & {$[118,119]$} \\
\hline - Experimental animal colonization is possible. & Bacillary forms of $\mathrm{H}$. pylori were used to colonize germ-free piglets. & [130] \\
\hline \multicolumn{3}{|l|}{ Water } \\
\hline $\begin{array}{l}\text { - Water contamination is a risk factor for } \mathrm{H} \text {. pylori } \\
\text { infection. }\end{array}$ & $\begin{array}{l}\text { Many reports, mostly from developing countries, suggested contaminated } \\
\text { water sources as risk factors. Examples include studies performed in Peru, } \\
\text { Chile, and Kazakhstan. }\end{array}$ & {$[105,131,132]$} \\
\hline - Water from running, municipal, and underground & - Municipal water & {$[105]$} \\
\hline sources, as well as wastewater has been suggested & - Well water & [133] \\
\hline \multirow[t]{3}{*}{ as reservoir for $H$. pylori. } & - Running water & {$[99,134]$} \\
\hline & - Wastewater & [135] \\
\hline & - H. pylori even survives in chlorinated water. & [136] \\
\hline - H. pylori proteins and DNA can be detected & - by immunological methods & {$[137]$} \\
\hline \multirow[t]{2}{*}{ in water. } & - by PCR & {$[133,138]$} \\
\hline & - by hybridization methods & [139] \\
\hline \multirow{3}{*}{$\begin{array}{l}\text { - Viable H. pylori can be detected and isolated } \\
\text { from water. }\end{array}$} & - as individual cells & [140] \\
\hline & - associated with biofilm & {$[141,142]$} \\
\hline & - cultured & [135] \\
\hline
\end{tabular}

Examples of studies on different environmental sources of $H$. pylori and their role in $H$. pylori transmission.

the relative risk of infection has been shown to increase according to the number of children per household $[60,75]$.

Additionally, spouse-to-spouse transmission was suggested [76,77]. Georgopoulos et al. found a significant number of couples infected with indistinguishable strains of $H$. pylori [76].

Finally, infected children were also proposed as a source of infection for parents or siblings [60,78]. However, a casecontrol study performed in Bangladesh found no difference in infection rates between parents of infected and non- infected infants, and concluded that in communities with high prevalence of $H$. pylori infection, interfamilial transmission might be masked by other environmental factors [79]

\section{Socioeconomic factors}

Socioeconomic status was reported as one of the most important factors affecting the spreading of $H$. pylori infection $[8,14,80]$. In particular, the high age-specific prevalence of $H$. pylori infection in developing countries has been attributed to low socioeconomic level [13]. By contrast, the lower prevalence of $H$. pylori infection in developed 
countries may be a result of higher socioeconomic status. The overall prevalence of $H$. pylori among Swiss adolescents was found to be $9.7 \%$. While this prevalence is among the lowest in Europe, further analysis indicated that subjects from foreign countries had higher rates of infection (30\%) than natives $(7.3 \%)$. This significant difference was largely attributed to higher living standards among natives [81].

In USA, Malaty et al. classified children into five social classes. The prevalence of the infection was $82 \%$ in the lowest class, $52 \%$ in the two middle classes, and $11 \%$ in the two high classes, demonstrating an inverse correlation between $H$. pylori prevalence and socioeconomic status [72].

Obviously, socioeconomic status is not restricted to income and social class but takes in consideration other factors, including living standards, sanitation, urbanization, and educational level [11]. Combined, these factors are likely to increase the risk for infectious diseases in general.

Educational level, in particular, has been used as a marker of socioeconomic status and has been considered as one of the important determinants of $H$. pylori prevalence in both developed [82] and developing countries [61]. Rosenstock et al. found that the short duration of schooling beside low socioeconomic status increases the likelihood of $H$. pylori infection in Denmark [82].

\section{Crowding index (Density of living)}

Household crowding, sharing a bed, and increasing household contact have been identified as risk factors of H. pylori infection $[9,61,83,84]$. In a large communitybased study, Torres and colleagues stated that density of living conditions is a prime determinant in the acquisition of $H$. pylori [61]. In childhood, crowded living conditions affect current $H$. pylori status, and the number of children in the present household increases the risk of infection for the adult family members [60].

\section{Conclusion}

The verdict: Is $H$. pylori a poverty-associated disease?

As with most infectious and non-infectious diseases, no one factor can be singled out as the major determinant of $H$. pylori incidence and prevalence. However, there is credible evidence that poverty-associated factors are major players.

The studies reviewed in this article show some evident differences in epidemiology between developing and developed countries, notably among children. However, we do not think that $H$. pylori prevalence is directly correlated with a country's overall wealth inasmuch as human poverty is not necessarily dependent on a country's gross domestic product (compare Fig. 2A with Fig. 2B). Instead, the effects of poverty on $H$. pylori infection are more pronounced between different communities, often located within the same country or region, but separated based on sanitation, overall hygiene, and standards of living. A good example is given in a recent study, conducted over 10 years, which showed that improved standards of living in Russia have substantially reduced $H$. pylori transmission [18].

\section{Outlook: Changing climate + changing demography + changing economy = redrawing the global map of H. pylori epidemiology}

"Out of every 100 persons added to the population in the coming decade, 97 will live in developing countries." Hania Zlotnik, 2005 [85] (Hania Zlotnik is the director of the Population Division, Department of Economic and Social Affairs, United Nations Secretariat)

The last question we address in this review article is about the future of $H$. pylori epidemiology. The foreseeable future, unfortunately, does not seem very promising for the developing countries. Although $H$. pylori infection may eventually disappear from high-income countries even without intervention, as suggested by mathematical modeling [86], its prevalence is paradoxically expected to rise in low-income countries and communities [87]. The changing climate is expected to change the world's demography, resources, and clean water availability [88]. Combined, these factors have direct impact on living standards and hygiene, and are thus not likely to slow down the rate of $H$. pylori acquisition in developing countries [89]. If we add to these factors the unequal population growth (Fig. 2C), the uneven economic growth, and the rise in life expectancy all over the world, the picture gets dimmer. A likely scenario is that this combination of factors will translate into higher incidence of $H$. pylori infection in children, who, according to Hania Zlotnik, the director of the Department of Economic and Social Affairs-United Nations Population Division, will mostly be born and live in developing countries [85]. This higher incidence in children will lead to a rise rather than fall of $H$. pylori's worldwide prevalence, and consequently to higher risk of gastric cancer especially in the elder population of the developing world (which are expected to live longer than they do today without necessarily being healthier).

Because of this serious risk, researchers should combine efforts and seek efficient methods to prevent H. pylori-associated diseases [87] and perhaps to eradicate this chronic colonizer of half of the human race [90]. 


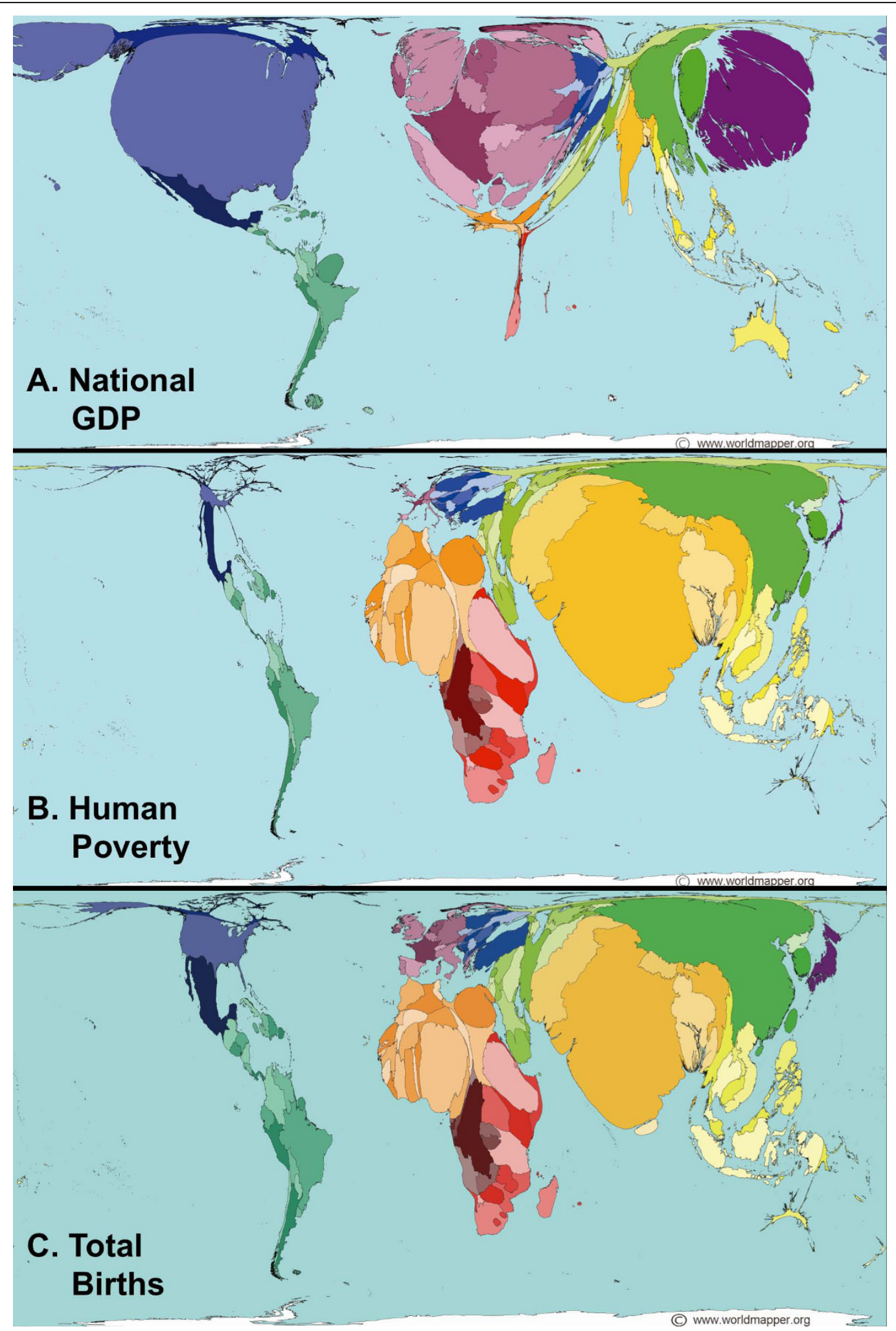

Figure 2 Cartograms showing the unequal distribution of (A) wealth, (B) human poverty indices, and (C) total births around the globe The cartograms, or map projections, were obtained from URL: http://www.worldmapper.org with permission ( ${ }^{\odot}$ Copyright SASI Group, University of Sheffield; and Mark Newman, University of Michigan). They had been generated by a diffusion-based method [91] and were included in the Worldmapper project [92-94]. 


\section{Author details}

'Department of Microbiology and Immunology, Faculty of Pharmacy, Cairo University, 11562 Cairo, Egypt. 'Faculty of Pharmacy, Cairo University, 11562 Cairo, Egypt.

\section{Authors' contributions}

MMK surveyed and reviewed the literature, and drafted the paper; RRS collected recent articles and participated in writing the final version of the paper; RKA analyzed the collected data, reviewed the socioeconomic literature, and wrote the paper in its final format. All authors read and approved the final manuscript.

\section{Authors' information}

Mohammed Mahdy Khalifa is a graduate student at the Faculty of Pharmacy, Cairo University, Cairo, Egypt. He received his master's degree in microbiology and immunology in 2009. Radwa Raed Sharaf is an undergraduate student at the Faculty of Pharmacy, Cairo University, Cairo, Egypt. Ramy Karam Aziz is currently a lecturer of microbiology and immunology at the Faculty of Pharmacy, Cairo University, Cairo, Egypt and an adjunct faculty member at San Diego State University, San Diego, CA, USA.

\section{Competing interests}

The authors declare that they have no competing interests regarding the publication of this review article.

Received: 9 March 2010 Accepted: 31 March 2010 Published: 31 March 2010

\section{References}

1. Warren JR, Marshall B: Unidentified curved bacilli on gastric epithelium in active chronic gastritis. Lancet 1983, 321:1273-1275.

2. Marshall BJ, Warren JR: Unidentified curved bacilli in the stomach of patients with gastritis and peptic ulceration. Lancet 1984, 1:1311-1315.

3. International Agency for Research on Cancer: Infection with Helicobacter pylori. IARC Monogr Eval Carcinog Risks Hum, 1994/01/01 1994, 61:177-240.

4. Peter S, Beglinger C: Helicobacter pylori and gastric cancer: the causal relationship. Digestion 2007, 75:25-35.

5. The EUROGAST Study Group: Epidemiology of, and risk factors for Helicobacter pylori infection among 3194 asymptomatic subjects in 17 populations. Gut 1993, 34:1672-1676.

6. Malaty HM, Graham DY, Wattigney WA, Srinivasan SR, Osato M, Berenson GS: Natural history of Helicobacter pylori infection in childhood: 12-year follow-up cohort study in a biracial community. Clin Infect Dis 1999, 28:279-282.

7. Pounder $\mathrm{RE}, \mathrm{Ng} \mathrm{D}$ : The prevalence of Helicobacter pylori infection in different countries. Aliment Pharmacol Ther 1995, 9(Suppl 2):33-39.

8. Malaty HM, Evans DG, Evans DJ Jr, Graham DY: Helicobacter pylori in Hispanics: comparison with blacks and whites of similar age and socioeconomic class. Gastroenterology 1992, 103:813-816.

9. Mitchell HM, Li YY, Hu PJ, Liu Q, Chen M, Du GG, Wang ZJ, Lee A, Hazell SL Epidemiology of Helicobacter pylori in southern China: identification of early childhood as the critical period foracquisition. J Infect Dis 1992, 166:149-153.

10. Goh KL: Prevalence of and risk factors for Helicobacter pylori infection in a multi-racial dyspeptic Malaysian population undergoing endoscopy. J Gastroenterol Hepatol 1997, 12:S29-35.

11. Mitchell HM: Epidemiology of infection. Helicobacter Pylori: Physiology and Genetics Washington, D.C.: ASM PressMobley HLT, Mendz GL, Hazell SL 2001.

12. Mégraud F, Brassens-Rabbe MP, Denis F, Belbouri A, Hoa DQ: Seroepidemiology of Campylobacter pylori infection in various populations. J Clin Microbiol 1989, 27:1870-1873.

13. Graham DY, Adam E, Reddy GT, Agarwal JP, Agarwal R, Evans DJ Jr Malaty HM, Evans DG: Seroepidemiology of Helicobacter pylori infection in India. Comparison of developing and developed countries 1991, 36:1084-1088

14. Bardhan PK: Epidemiological features of Helicobacter pylori infection in developing countries. Clin Infect Dis 1997, 25:973-978.

15. Perez-Perez Gl, Rothenbacher D, Brenner H: Epidemiology of Helicobacter pylori infection. Helicobacter 2004, 9(Suppl 1):1-6.
16. Salih BA: Helicobacter pylori infection in developing countries: the burden for how long? Saudi J Gastroenterol 2009, 15:201-207.

17. Feldman RA, Eccersley AJ, Hardie JM: Epidemiology of Helicobacter pylori : acquisition, transmission, population prevalence and disease-to-infection ratio. Br Med Bull 1998, 54:39-53.

18. Tkachenko MA, Zhannat NZ, Erman LV, Blashenkova EL, Isachenko SV, Isachenko OB, Graham DY, Malaty HM: Dramatic changes in the prevalence of Helicobacter pylori infection during childhood: a 10-year follow-up study in Russia. J Pediatr Gastroenterol Nutr 2007, 45:428-432.

19. Brown LM: Helicobacter pylori : epidemiology and routes of transmission. Epidemiol Rev 2000, 22:283-297.

20. Dooley CP, Cohen H, Fitzgibbons PL, Bauer M, Appleman MD, PerezPerez GI, Blaser MJ: Prevalence of Helicobacter pylori infection and histologic gastritis in asymptomatic persons. N Engl J Med 1989, 321:1562-1566

21. Taylor DN, Blaser MJ: The epidemiology of Helicobacter pylori infection. Epidemiol Rev 1991, 13:42-59.

22. Weaver LT: Royal Society of Tropical Medicine and Hygiene Meeting at Manson House, London, 16 February 1995. Aspects of Helicobacter pylori infection in the developing and developed world. Helicobacter pylori infection, nutrition and growth of West African infants. Trans $R$ Soc Trop Med Hyg 1995, 89:347-350.

23. Rothenbacher $\mathrm{D}$, Brenner $\mathrm{H}$ : Burden of Helicobacter pylori and $\mathrm{H}$. pylorirelated diseases in developed countries: recent developments and future implications. Microbes Infect 2003, 5:693-703.

24. Sack RB, Gyr K: Helicobacter pylori infections in the developing world. Summary of a workshop organized at the International Centre for Diarrhoeal Disease Research, Bangladesh (ICDDR, B) from February 2 to 4, 1993. J Diarrhoeal Dis Res 1994, 12:144-145.

25. Song Q, Lange T, Spahr A, Adler G, Bode G: Characteristic distribution pattern of Helicobacter pylori in dental plaque and saliva detected with nested PCR. J Med Microbiol 2000, 49:349-353.

26. Lin SK, Lambert JR, Schembri MA, Nicholson L, Korman MG: Helicobacter pylori prevalence in endoscopy and medicalstaff. J Gastroenterol Hepatol 1994, 9:319-324.

27. el-Zaatari FA, Nguyen AM, Genta RM, Klein PD, Graham DY: Determination of Helicobacter pylori status by reverse transcription-polymerase chain reaction. Comparison with urea breath test. Dig Dis Sci 1995, 40:109-113.

28. Perry S, de la Luz Sanchez M, Yang S, Haggerty TD, Hurst P, Perez-Perez G, Parsonnet J: Gastroenteritis and transmission of Helicobacter pylori infection in households. Emerg Infect Dis 2006, 12:1701-1708.

29. Solnick JV, Fong J, Hansen LM, Chang K, Canfield DR, Parsonnet J: Acquisition of Helicobacter pylori infection in rhesus macaques is most consistent with oral-oral transmission. J Clin Microbiol 2006, 44:3799-3803.

30. Albenque $M$, Tall $F$, Dabis F, Mégraud F: Epidemiological study of Helicobacter pylori transmission from mother to child inAfrica. Rev Esp Enferm Dig 1990, 78

31. Chow TK, Lambert JR, Wahlqvist ML, Hsu-Hage BH: Helicobacter pylori in Melbourne Chinese immigrants: evidence for oral-oral transmission via chopsticks. J Gastroenterol Hepatol 1995, 10:562-569.

32. Lambert JR, Lin SK, Sievert W, Nicholson L, Schembri M, Guest C: High prevalence of Helicobacter pylori antibodies in an institutionalized population: evidence for person-to-persontransmission. $\mathrm{Am} J$ Gastroenterol 1995, 90:2167-2171.

33. Leung WK, Sung JJ, Ling TK, Siu KL, Cheng AF: Use of chopsticks for eating and Helicobacter pylori infection. Dig Dis Sci 1999, 44:1173-1176.

34. Mapstone NP, Lynch DA, Lewis FA, Axon AT, Tompkins DS, Dixon MF, Quirke P: Identification of Helicobacter pylori DNA in the mouths and stomachs of patients with gastritis using PCR. J Clin Pathol 1993, 46:540-543.

35. Banatvala N, Lopez CR, Owen R, Abdi Y, Davies G, Hardie J, Feldman R: Helicobacter pylori in dental plaque. Lancet 1993, 341:380.

36. Dowsett SA, Archila L, Segreto VA, Gonzalez CR, Silva A, Vastola KA, Bartizek RD, Kowolik MJ: Helicobacter pylori infection in indigenous families of Central America: serostatus and oral and fingernail carriage. $J$ Clin Microbiol 1999, 37:2456-2460

37. Krajden S, Fuksa M, Anderson J, Kempston J, Boccia A, Petrea C, Babida C, Karmali M, Penner JL: Examination of human stomach biopsies, saliva, and dental plaque for Campylobacter pylori. J Clin Microbiol 1989, 27:1397-1398. 
38. Shames B, Krajden S, Fuksa M, Babida C, Penner JL: Evidence for the occurrence of the same strain of Campylobacter pylori in the stomach and dental plaque. J Clin Microbiol 1989, 27:2849-2850.

39. Cellini L, Allocati N, Piattelli A, Petrelli I, Fanci P, Dainelli B: Microbiological evidence of Helicobacter pylori from dental plaque in dyspeptic patients. New Microbiol 1995, 18:187-192.

40. Bickley J, Owen RJ, Fraser AG, Pounder RE: Evaluation of the polymerase chain reaction for detecting the urease $\mathrm{C}$ gene of Helicobacter pylori in gastric biopsy samples and dental plaque. J Med Microbiol 1993, 39:338-344.

41. Cammarota G, Tursi A, Montalto M, Papa A, Veneto G, Bernardi S, Boari A, Colizzi V, Fedeli G, Gasbarrini G: Role of dental plaque in the transmission of Helicobacter pylori infection. J Clin Gastroenterol 1996, 22:174-177.

42. Luzza F, Mancuso M, Imeneo M, Contaldo A, Giancotti L, Pensabene L, Doldo P, Liberto MC, Strisciuglio P, Foca A, et al: Evidence favouring the gastro-oral route in the transmission of Helicobacter pylori infection in children. Eur J Gastroenterol Hepatol 2000, 12:623-627.

43. Mitchell HM, Lee A, Carrick J: Increased incidence of Campylobacter pylori infection in gastroenterologists: further evidence to support person-toperson transmission of C. pylori. Scand J Gastroenterol 1989, 24:396-400.

44. Varoli O, Landini MP, LaPlaca M, Tucci A, Corinaldesi R, Paparo GF, Stanghellini V, Barbara L: Presence of Helicobacter pylori in gastric juice. Am J Gastroenterol 1991, 86:249.

45. Mitchell JD, Mitchell HM, Tobias V: Acute Helicobacter pylori infection in an infant, associated with gastric ulceration and serological evidence of intra-familial transmission. Am J Gastroenterol 1992, 87:382-386.

46. Leung WK, Siu KL, Kwok CK, Chan SY, Sung R, Sung JJ: Isolation of Helicobacter pylori from vomitus in children and its implication in gastrooral transmission. Am J Gastroenterol 1999, 94:2881-2884.

47. Parsonnet J, Shmuely H, Haggerty T: Fecal and oral shedding of Helicobacter pylori from healthy infected adults. JAMA 1999, 282:2240-2245.

48. Ramsey EJ, Carey KV, Peterson WL, Jackson JJ, Murphy FK, Read NW, Taylor KB, Trier JS, Fordtran JS: Epidemic gastritis withhypochlorhydria. Gastroenterology 1979, 76:1449-1457.

49. Graham DY, Alpert LC, Smith JL, Yoshimura HH: latrogenic Campylobacter pylori infection is a cause of epidemicachlorhydria. Am J Gastroenterol 1988, 83:974-980.

50. Mitchell HM, Li Y, Hu P, Hazell SL, Du GG, Byrne DJ, Lee A: The susceptibility of Helicobacter pylori to bile may be an obstacle to faecal transmission. Eur I Gastroenterol Hepatol 1992, 4:S79-S83.

51. Dye KR, Marshall BJ, Frierson HF Jr, Pambianco DJ, McCallum RW: Campylobacter pylori colonizing heterotopic gastric tissue in the rectum. Am J Clin Pathol 1990, 93:144-147.

52. Mapstone NP, Lynch DA, Lewis FA, Axon AT, Tompkins DS, Dixon MF, Quirke P: PCR identification of Helicobacter pylori in faeces from gastritis patients. Lancet 1993, 341:447.

53. van Zwet AA, Thijs JC, Kooistra-Smid AM, Schirm J, Snijder JA: Use of PCR with feces for detection of Helicobacter pylori infections in patients. $J$ Clin Microbiol 1994, 32:1346-1348.

54. Namavar F, Roosendaal R, Kuipers EJ, de Groot P, Bijl van der MW, Pena AS, de Graaff J: Presence of Helicobacter pylori in the oral cavity, oesophagus, stomach and faeces of patients with gastritis. Eur I Clin Microbiol Infect Dis 1995, 14:234-237.

55. Li C, Ha T, Ferguson DA Jr, Chi DS, Zhao R, Patel NR, Krishnaswamy G, Thomas E: A newly developed PCR assay of $H$. pylori in gastric biopsy, saliva, and feces. Evidence of high prevalence of $H$. pylori in saliva supports oral transmission. Dig Dis Sci 1996, 41:2142-2149.

56. Thomas JE, Gibson GR, Darboe MK, Dale A, Weaver LT: Isolation of Helicobacter pylori from human faeces. Lancet 1992, 340:1194-1195.

57. Kelly SM, Pitcher MC, Farmery SM, Gibson GR: Isolation of Helicobacter pylori from feces of patients with dyspepsia in the United Kingdom. Gastroenterology 1994, 107:1671-1674.

58. Mégraud F: Transmission of Helicobacter pylori : faecal-oral versus oraloral route. Aliment Pharmacol Ther 1995, 9(Suppl 2):85-91.

59. Graham DY, Malaty HM, Evans DG, Evans DJ Jr, Klein PD, Adam E: Epidemiology of Helicobacter pylori in an asymptomatic population in the United States. Effect of age, race, and socioeconomic status. Gastroenterology 1991, 100:1495-1501.
60. Breuer T, Sudhop T, Hoch J, Sauerbruch T, Malfertheiner P: Prevalence of and risk factors for Helicobacter pylori infection in the western part of Germany. Eur J Gastroenterol Hepatol 1996, 8:47-52.

61. Torres J, Leal-Herrera Y, Perez-Perez G, Gomez A, Camorlinga-Ponce M, Cedillo-Rivera R, Tapia-Conyer R, Munoz O: A community-based seroepidemiologic study of Helicobacter pylori infection inMexico. I Infect Dis 1998, 178:1089-1094.

62. Parsonnet J: The incidence of Helicobacterpylori infection. Aliment Pharmacol Ther 1995, 9(Suppl 2):45-51.

63. Fujisawa T, Kumagai T, Akamatsu T, Kiyosawa K, Matsunaga Y: Changes in seroepidemiological pattern of Helicobacter pylori and hepatitis A virus over the last 20 years in Japan. Am J Gastroenterol 1999, 94:2094-2099.

64. Fraser AG, Scragg R, Metcalf P, McCullough S, Yeates NJ: Prevalence of Helicobacter pylori infection in different ethnic groups in New Zealand children and adults. Aust N Z J Med 1996, 26:646-651.

65. Malaty HM, Engstrand L, Pedersen NL, Graham DY: Helicobacter pylori infection: genetic and environmental influences. A study oftwins. Ann Intern Med 1994, 120:982-986.

66. Smoak BL, Kelley PW, Taylor DN: Seroprevalence of Helicobacter pylori infections in a cohort of US Army recruits. Am J Epidemiol 1994, 139:513-519.

67. Replogle ML, Glaser SL, Hiatt RA, Parsonnet J: Biologic sex as a risk factor for Helicobacter pylori infection in healthy youngadults. Am J Epidemiol 1995, 142:856-863.

68. Woodward M, Morrison C, McColl K: An investigation into factors associated with Helicobacter pylori infection. J Clin Epidemiol 2000, 53:175-181.

69. Kawasaki M, Kawasaki T, Ogaki T, Itoh K, Kobayashi S, Yoshimizu Y, Aoyagi K, Iwakawa A, Takahashi S, Sharma S, Acharya GP: Seroprevalence of Helicobacter pylori infection in Nepal: low prevalence in an isolated rural village. Eur J Gastroenterol Hepatol 1998, 10:47-50.

70. Begue RE, Gonzales JL, Correa-Gracian H, Tang SC: Dietary risk factors associated with the transmission of Helicobacter pylori in Lima, Peru. Am J Trop Med Hyg 1998, 59:637-640.

71. de Martel C, Parsonnet J: Helicobacter pylori infection and gender: a meta-analysis of population-based prevalence surveys. Dig Dis Sci 2006, 51:2292-2301.

72. Malaty HM, Graham DY: Importance of childhood socioeconomic status on the current prevalence of Helicobacter pylori infection. Gut 1994 35:742-745.

73. Rothenbacher D, Bode G, Berg G, Knayer U, Gonser T, Adler G, Brenner H: Helicobacter pylori among preschool children and their parents: evidence of parent-child transmission. J Infect Dis 1999, 179:398-402.

74. Konno M, Fujii N, Yokota S, Sato K, Takahashi M, Mino E, Sugiyama T: Fiveyear follow-up study of mother-to-child transmission of Helicobacter pylori infection detected by a random amplified polymorphic DNA fingerprinting method. J Clin Microbiol 2005, 43:2246-2250.

75. Goodman KJ, Correa P: The transmission of Helicobacter pylori. A critical review of the evidence. Int J Epidemiol 1995, 24:875-887.

76. Georgopoulos SD, Mentis AF, Spiliadis CA, Tzouvelekis LS, Tzelepi E, Moshopoulos A, Skandalis N: Helicobacter pylori infection in spouses of patients with duodenal ulcers and comparison of ribosomal RNA gene patterns. Gut 1996, 39:634-638.

77. Brenner $H$, Rothenbacher D, Bode G, Dieudonne P, Adler G: Active infection with Helicobacter pylori in healthy couples. Epidemiol Infect 1999, 122:91-95.

78. Teh BH, Lin JT, Pan WH, Lin SH, Wang LY, Lee TK, Chen CJ: Seroprevalence and associated risk factors of Helicobacter pylori infection in Taiwan. Anticancer Res 1994, 14:1389-1392.

79. Sarker SA, Rahman MM, Mahalanabis D, Bardhan PK, Hildebrand P, Beglinger C, Gyr K: Prevalence of Helicobacter pylori infection in infants and family contacts in a poor Bangladesh community. Dig Dis Sci 1995, 40:2669-2672.

80. Malcolm CA, MacKay WG, Shepherd A, Weaver LT: Helicobacter pylori in children is strongly associated with poverty. Scott Med J 2004, 49:136-138.

81. Heuberger F, Pantoflickova D, Gassner M, Oneta C, Grehn M, Blum AL, Dorta G: Helicobacter pylori infection in Swiss adolescents: prevalence and risk factors. Eur J Gastroenterol Hepatol 2003, 15:179-183. 
82. Rosenstock SJ, Andersen LP, Rosenstock CV, Bonnevie O, Jørgensen T: Socioeconomic factors in Helicobacter pylori infection among Danish adults. Am J Public Health 1996, 86:1539-1544.

83. Mendall MA, Goggin PM, Molineaux N, Levy J, Toosy T, Strachan D, Northfield TC: Childhood living conditions and Helicobacter pylori seropositivity in adult life. Lancet 1992, 339:896-897.

84. McCallion WA, Murray $\amalg$, Bailie AG, Dalzell AM, O'Reilly DP, Bamford KB: Helicobacter pylori infection in children: relation with current household living conditions. Gut 1996, 39:18-21.

85. Zlotnik H: Statement to the Thirty-Eighth Session on the Commission on Population and Development. 2005.

86. Rupnow MF, Shachter RD, Owens DK, Parsonnet J: A dynamic transmission model for predicting trends in Helicobacter pylori and associated diseases in the United States. Emerg Infect Dis 2000, 6:228-237.

87. Ahmed N, Tenguria S, Nandanwar N: Helicobacter pylori - a seasoned pathogen by any other name. Gut Pathog 2009, 1:24.

88. World Health Organization: Safe water, better health. 2008

89. Blaser MJ: Theodore E. Woodward Award: Global warming and the human stomach: microecology follows macroecology. Trans Am Clin Climatol Assoc 2005, 116:65-75, discussion 75-66.

90. Graham DY, Yamaoka Y, Malaty HM: Contemplating the future without Helicobacter pylori and the dire consequences hypothesis. Helicobacter 2007, 2:64-68.

91. Gastner MT, Newman ME: From The Cover: Diffusion-based method for producing density-equalizing maps. Proc Natl Acad Sci USA 2004, 101:7499-7504

92. Dorling D: Worldmapper: the human anatomy of a smallplanet. PLoS Med 2007, 4:e1.

93. Dorling D, Barford A, Newman M: WORLDMAPPER: the world as you've never seen it before. IEEE Trans Vis Comput Graph 2006, 12:757-764.

94. Barford A, Dorling D: A new approach to mapping the world: visualizing facets of international health. Natl Med J India 2006, 19:234-235.

95. Ahmad MM, Rahman M, Rumi AK, Islam S, Huq F, Chowdhury MF, Jinnah F, Morshed MG, Hassan MS, Khan AK, Hasan M: Prevalence of Helicobacter pylori in asymptomatic population-a pilot serological study inBangladesh. J Epidemiol 1997, 7:251-254.

96. Souto FJ, Fontes CJ, Rocha GA, de Oliveira AM, Mendes EN, Queiroz DM: Prevalence of Helicobacter pylori infection in a rural area of the state of Mato Grosso, Brazil. Mem Inst Oswaldo Cruz 1998, 93:171-174.

97. Santos IS, Boccio J, Santos AS, Valle NC, Halal CS, Bachilli MC, Lopes RD: Prevalence of Helicobacter pylori infection and associated factors among adults in Southern Brazil: a population-based cross-sectional study. BMC Public Health 2005, 5:118.

98. Rodrigues MN, Queiroz DM, Rodrigues RT, Rocha AM, Braga Neto MB, Braga LL: Helicobacter pylori infection in adults from a poor urban community in northeastern Brazil: demographic, lifestyle and environmental factors. Braz J Infect Dis 2005, 9:405-410.

99. Goodman KJ, Correa P, Tenganá Aux HJ, Ramírez H, DeLany JP, Guerrero Pepinosa O, López Quiñones M, Collazos Parra T: Helicobacter pylori infection in the Colombian Andes: a population-based study of transmission pathways. Am J Epidemiol 1996, 144:290-299.

100. Wong BC, Lam SK, Ching CK, Hu WH, Kwok E, Ho J, Yuen ST, Gao Z, Chen JS, Lai KC, et al: Differential Helicobacter pylori infection rates in two contrasting gastric cancer risk regions of South China. China Gastric Cancer Study Group. J Gastroenterol Hepatol 1999, 14:120-125.

101. Bassily S, Frenck RW, Mohareb EW, Wierzba T, Savarino S, Hall E, Kotkat A, Naficy A, Hyams KC, Clemens J: Seroprevalence of Helicobacter pylori among Egyptian newborns and their mothers: a preliminaryreport. Am J Trop Med Hyg 1999, 61:37-40.

102. Frenck RW Jr, Fathy HM, Sherif M, Mohran Z, El Mohammedy H, Francis W, Rockabrand D, Mounir BI, Rozmajzl P, Frierson HF: Sensitivity and specificity of various tests for the diagnosis of Helicobacter pylori in Egyptian children. Pediatrics 2006, 118:e1195-1202.

103. Sayed ASM, Abd Al Azeem MW, Noaman HA, Hassan MA: Seroepidemiological study on $\mathrm{H}$. pylori infection in children and adults in Assiut governorate, Upper Egypt. JASMR 2007, 2:129-133.

104. Mohammad MA, Hussein L, Coward A, Jackson SJ: Prevalence of Helicobacter pylori infection among Egyptian children: impact of social background and effect on growth. Public Health Nutr 2008, 11:230-236.
105. Klein PD, Graham DY, Gaillour A, Opekun AR, Smith EO: Water source as risk factor for Helicobacter pylori infection in Peruvian children. Gastrointestinal Physiology Working Group. Lancet 1991, 337:1503-1506.

106. Malaty HM, Paykov V, Bykova O, Ross A, Graham DP, Anneger JF, Graham DY: Helicobacter pylori and socioeconomic factors inRussia. Helicobacter 1996, 1:82-87.

107. Al-Moagel MA, Evans DG, Abdulghani ME, Adam E, Evans DJ Jr, Malaty HM, Graham DY: Prevalence of Helicobacter (formerly Campylobacter) pylori infection in Saudia Arabia, and comparison of those with and without upper gastrointestinal symptoms. Am J Gastroenterol 1990, 85:944-948.

108. Andersen LP, Rosenstock SJ, Bonnevie O, Jorgensen T: Seroprevalence of immunoglobulin G, M, and A antibodies to Helicobacter pylori in an unselected Danish population. Am J Epidemiol 1996, 143:1157-1164.

109. Gilboa S, Gabay G, Zamir D, Zeev A, Novis B: Helicobacter pylori infection in rural settlements (Kibbutzim) in Israel. Int J Epidemiol 1995, 24:232-237.

110. Kikuchi S, Kurosawa M, Sakiyama T: Helicobacter pylori risk associated with sibship size and family history of gastric diseases in Japanese adults. Jpn J Cancer Res 1998, 89:1109-1112.

111. Böhmer CJ, Klinkenberg-Knol EC, Kuipers EJ, Niezen-de Boer MC, Schreuder H, Schuckink-Kool F, Meuwissen SG: The prevalence of Helicobacter pylori infection among inhabitants and healthy employees of institutes for the intellectually disabled. Am J Gastroentero/ 1997, 92:1000-1004

112. Senra-Varela A, Lopez-Saez JB, Gomez-Biondi V: Prevalence of Helicobacter pylori infection in two Spanish regions with different incidence of gastric cancer. Eur J Epidemiol 1998, 14:491-494.

113. Malaty HM, Kim JG, Kim SD, Graham DY: Prevalence of Helicobacter pylori infection in Korean children: inverse relation to socioeconomic status despite a uniformly high prevalence inadults. Am J Epidemiol 1996, 143:257-262.

114. Harris AW, Douds A, Meurisse EV, Dennis M, Chambers S, Gould SR: Seroprevalence of Helicobacter pylori in residents of a hospital for people with severe learning difficulties. Eur J Gastroenterol Hepatol 1995, 7:21-23.

115. Webb PM, Knight T, Newell DG, Elder JB, Forman D: Helicobacter pylori transmission: evidence from a comparison with hepatitis Avirus. Eur $J$ Gastroenterol Hepatol 1996, 8:439-441.

116. Murray $\amalg$, McCrum EE, Evans AE, Bamford KB: Epidemiology of Helicobacter pylori infection among 4742 randomly selected subjects from Northern Ireland. Int J Epidemiol 1997, 26:880-887.

117. Strachan DP, Mendall MA, Carrington D, Butland BK, Yarnell JW, Sweetnam PM, Elwood PC: Relation of Helicobacter pylori infection to 13year mortality and incident ischemic heart disease in the caerphilly prospective heart disease study. Circulation 1998, 98:1286-1290.

118. Dore MP, Sepulveda AR, Osato MS, Realdi G, Graham DY: Helicobacter pylori in sheep milk. Lancet 1999, 354:132.

119. Fujimura S, Kawamura T, Kato S, Tateno H, Watanabe A: Detection of Helicobacter pylori in cow's milk. Lett Appl Microbiol 2002, 35:504-507.

120. Bronsdon MA, Schoenknecht FD: Campylobacter pylori isolated from the stomach of the monkey, Macaca nemestrina. J Clin Microbiol 1988 26:1725-1728.

121. Handt LK, Fox JG, Yan LL, Shen Z, Pouch WJ, Ngai D, Motzel SL, Nolan TE, Klein HJ: Diagnosis of Helicobacter pylori infection in a colony of rhesus monkeys (Macaca mulatta). J Clin Microbiol 1997, 35:165-168.

122. Handt LK, Fox JG, Dewhirst FE, Fraser GJ, Paster BJ, Yan LL, Rozmiarek H, Rufo R, Stalis $\mathrm{IH}$ : Helicobacter pylori isolated from the domestic cat: public health implications. Infect Immun 1994, 62:2367-2374.

123. Dore MP, Sepulveda AR, El-Zimaity H, Yamaoka Y, Osato MS, Mototsugu K, Nieddu AM, Realdi G, Graham DY: Isolation of Helicobacter pylori from sheep-implications for transmission to humans. Am J Gastroenterol 2001 96:1396-1401.

124. Imamura S, Kita M, Yamaoka $Y$, Yamamoto $T$, Ishimaru A, Konishi H, Wakabayashi N, Mitsufuji S, Okanoue T, Imanishi J: Vector potential of cockroaches for Helicobacter pylori infection. Am J Gastroenterol 2003, 98:1500-1503.

125. Grübel P, Hoffman JS, Chong FK, Burstein NA, Mepani C, Cave DR: Vector potential of houseflies (Musca domestica) for Helicobacter pylori. J Clin Microbiol 1997, 35:1300-1303. 
126. Osato MS, Ayub K, Le HH, Reddy R, Graham DY: Houseflies are an unlikely reservoir or vector for Helicobacter pylori. J Clin Microbiol 1998, 36:2786-2788.

127. Morris A, Nicholson G, Lloyd G, Haines D, Rogers A, Taylor D: Seroepidemiology of Campylobacter pyloridis. N Z Med J 1986, 99:657-659.

128. Vaira D, D'Anastasio C, Holton J, Dowsett JF, Londei M, Bertoni F, Beltrandi E, Grauenfels P, Salmon PR, Gandolfi L: Campylobacter pylori in abattoir workers: is it a zoonosis? Lancet 1988, 2:725-726.

129. Dore MP, Bilotta M, Vaira D, Manca A, Massarelli G, Leandro G, Atzei A, Pisanu G, Graham DY, Realdi G: High prevalence of Helicobacter pylori infection in shepherds. Dig Dis Sci 1999, 44:1161-1164.

130. Eaton KA, Catrenich CE, Makin KM, Krakowka S: Virulence of coccoid and bacillary forms of Helicobacter pylori in gnotobiotic piglets. I Infect Dis 1995, 171:459-462.

131. Hopkins RJ, Vial PA, Ferreccio C, Ovalle J, Prado P, Sotomayor V, Russell RG, Wasserman SS, Morris JG Jr: Seroprevalence of Helicobacter pylori in Chile: vegetables may serve as one route of transmission. $J$ Infect Dis 1993, 168:222-226.

132. Nurgalieva ZZ, Malaty HM, Graham DY, Almuchambetova R, Machmudova A, Kapsultanova D, Osato MS, Hollinger FB, Zhangabylov A: Helicobacter pylori infection in Kazakhstan: effect of water source and household hygiene. Am J Trop Med Hyg 2002, 67:201-206.

133. Horiuchi T, Ohkusa T, Watanabe M, Kobayashi D, Miwa H, Eishi Y: Helicobacter pylori DNA in drinking water in Japan. Microbiol Immunol 2001, 45:515-519.

134. Fujimura S, Kato S, Watanabe A: Water source as a Helicobacter pylori transmission route: a 3-year follow-up study of Japanese children living in a unique district. J Med Microbiol 2008, 57:909-910.

135. Lu Y, Redlinger TE, Avitia R, Galindo A, Goodman K: Isolation and genotyping of Helicobacter pylori from untreated municipal wastewater. Appl Environ Microbiol 2002, 68:1436-1439.

136. Moreno Y, Piqueres P, Alonso JL, Jimenez A, Gonzalez A, Ferrus MA: Survival and viability of Helicobacter pylori after inoculation into chlorinated drinking water. Water Res 2007, 41:3490-3496.

137. Hultén K, Han SW, Enroth H, Klein PD, Opekun AR, Gilman RH, Evans DG, Engstrand L, Graham DY, El-Zaatari FA: Helicobacter pylori in the drinking water in Peru. Gastroenterology 1996, 110:1031-1035.

138. Hultén K, Enroth H, Nystrom T, Engstrand L: Presence of Helicobacter species DNA in Swedish water. J Appl Microbiol 1998, 85:282-286.

139. Moreno Y, Ferrus MA, Alonso JL, Jimenez A, Hernandez J: Use of fluorescent in situ hybridization to evidence the presence of Helicobacter pylori in water. Water Res 2003, 37:2251-2256.

140. Shahamat M, Mai U, Paszko-Kolva C, Kessel M, Colwell RR: Use of autoradiography to assess viability of Helicobacter pylori in water. Appl Environ Microbiol 1993, 59:1231-1235.

141. Azevedo NF: Survival of Helicobacter pylori in drinking water and associated biofilms. University of Minho and University of South hampton 2005.

142. Gião MS, Azevedo NF, Wilks SA, Vieira MJ, Keevil CW: Persistence of Helicobacter pylori in heterotrophic drinking-water biofilms. Appl Environ Microbiol 2008, 74:5898-5904.

doi:10.1186/1757-4749-2-2

Cite this article as: Khalifa et al: Helicobacter pylori: a poor man's gut pathogen? Gut Pathogens 2010 2:2.

\section{Submit your next manuscript to BioMed Central and take full advantage of:}

- Convenient online submission

- Thorough peer review

- No space constraints or color figure charges

- Immediate publication on acceptance

- Inclusion in PubMed, CAS, Scopus and Google Scholar

- Research which is freely available for redistribution

Submit your manuscript at www.biomedcentral.com/submit 